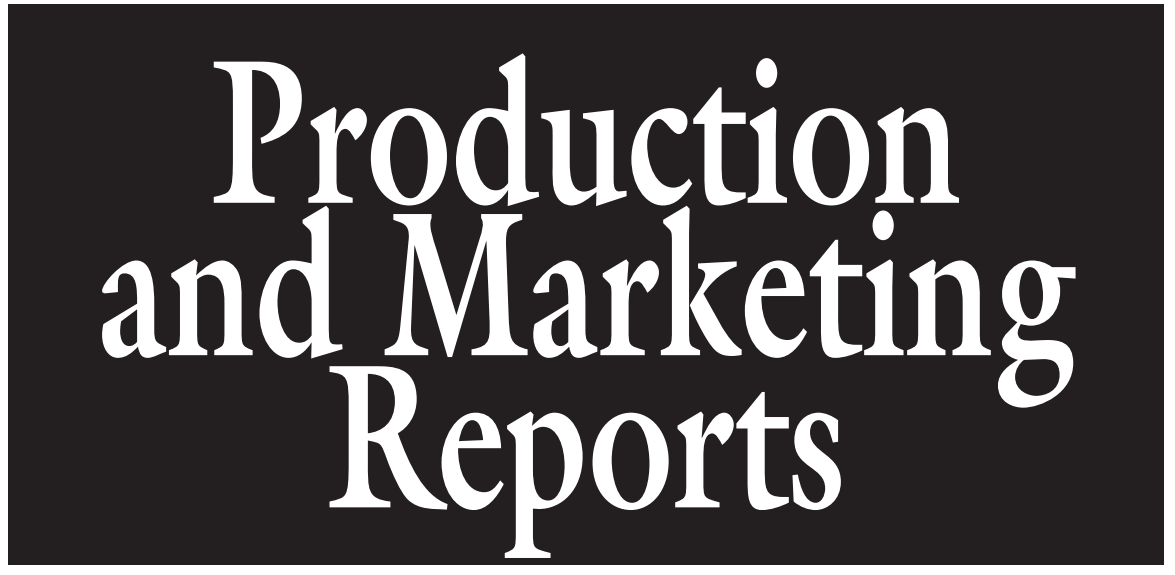

\title{
Survey of Consumer Interest in Organic, Sustainable, and Local Container-grown Plants in Maine
}

\author{
Gwendolyn Hawkins $^{1}$, Stephanie E. Burnett ${ }^{1,3}$, and Lois B. Stack ${ }^{1,2}$
}

ADDITIONAL INDEX WORDs. marketing, consumer behavior, ornamental, vegetables, herbs

SUMMARY. In 2008, we administered a survey to participants at four venues in Maine to determine: 1) the degree of interest in organically, sustainably, and locally grown plants; 2 ) whether respondents would pay more for these plants compared with conventional plants; and 3) which demographic groups expressed the greatest interest in organically, sustainably, or locally grown plants. Respondents were highly interested in organic and sustainable vegetable/herb and ornamental plants; median interest was 9 on a scale of 1 to 10 where 1 indicated low interest and 10 indicated high interest. They were less interested in locally grown plants; respondents' median interest in local plants was 6 on the same scale. Survey respondents stated that they would pay $\mathbf{1 5 \%}$ more (vegetable/ herbs) or $10 \%$ more (ornamentals) for organic, sustainable, or local plants than they would for conventionally grown plants. Several demographic factors indicated that respondents were either willing to spend more money on nonconventional plants, or were at least more interested in these kinds of plants. Income and education were positively correlated with the amount of money respondents stated they would spend on nonconventional plants. Younger participants were more interested than older participants in sustainable and organic plants, but they were not willing to pay more for these plants than older participants. Similarly, women were more interested than men in nonconventional plants, but were not likely to spend more on them than men. This survey indicated that there is a strong market for organic and sustainable vegetable, herb, and ornamental plants. Growers could potentially charge $10 \%$ to $15 \%$ more for these plants than for conventionally grown plants. They would likely receive the highest premium for organic and sustainable plants from individuals with higher incomes and education levels.

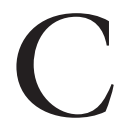

onsumer interest in certified organic produce and plants has increased in recent years. Worldwide, organic produce markets increased 20\% every year between 1999 and 2004 (Willer and Yussefi, 2004). Fruit and vegetables were the top grossing organic crops in 2006 [U.S. Department of Agriculture (USDA), 2006]. But, there is evidence of a growing nonfood organic to reduce environmental degradation, maintain agricultural productivity, promote economic viability, conserve energy and resources, and maintain quality of life and stable communities” (Krug et al., 2008). Sloan (2005) identified sustainability as one of the top 10 global food trends. Consumers surveyed in Minnesota reported that they would pay up to $10 \%$ to $30 \%$ more for sustainable foods, but they considered sustainability less important than food healthfulness, safety, and taste (Robinson et al., 2002).

A third emerging niche market is the locally grown produce and plant market. Yue and Tong (2009) reported that consumers in Minnesota were willing to pay similar amounts of money for both organically and locally produced food, and that consumers will frequent different types of venues to obtain organic or local produce. Consumer convictions about product quality and freshness, food safety, and support of domestic agriculture were all important factors in the decision to purchase locally in Germany (Henseleit et al., 2007). Concerns about global climate change may also have been an important factor in consumers' decisions to purchase locally (Blanke and Burdick, 2005; Pollan, 2006). However, consumers in Ohio found the term "local" difficult to define; they considered products produced "in state" and "nearby" of similar value (Darby et al., 2008).

To date, much of the research on the organic, sustainable, and local movements in agriculture has focused on food, and not green industry products such as container-grown vegetables, herbs, and ornamentals. Yet, there is little to suggest that the interest in organic, sustainable, and local products is limited to food. Identifying market interest in organic, sustainable, and local container-grown plants would provide growers with the necessary information to ascertain whether this is a viable market niche for their respective firms. We surveyed frequent plant purchasers with two objectives. First, we sought to determine whether there is a market for local, sustainable, or organic container-grown plants. Further, we wished to gauge consumers' willingness to pay for organic, sustainable, and local plants and to identify which factors may be predictive of respondents most likely to purchase these plants. 


\section{Materials and methods}

A survey was developed to determine respondent interest in organically, sustainably, and locally grown plants (Table 1). The University of Maine Institutional Review Board for the Protection of Human Subjects approved the survey, and participation in the survey was limited to subjects aged 18 years or older. An early draft was pretested in a college class of 10 students to detect potential errors.

The survey was administered to voluntary participants at four venues in Maine: the Portland Flower Show (Portland, ME) on 8 Mar. 2008, the Bangor Garden Show (Bangor, ME) on 5 Apr. 2008, Longfellow's Greenhouses' (Manchester, ME) open house on 26 Apr. 2008, and the Coastal Maine Botanical Gardens' (Boothbay Harbor, ME) garden show on 6 June 2008 . The rationale for having a variety of venues was to attract a wider demographic cross section than might be attracted to a single venue. At each venue, several copies of the survey attached to clipboards were available so that several volunteers could complete surveys at one time. There was a degree of self-selection in the procedure. However, we made every effort to approach all passersby, to ask if they would like to participate in the survey. In this sense, we had a "foot in the door" approach and were able to explain the importance of the research to potential participants. The survey was self-administered, but staff were available to field questions about the survey or the larger research project. Since the survey took place at gardening events, our sampling frame only included those people who participated in those events and did not include the larger plant-purchasing

Maine Agriculture and Forestry Experiment Station Publication No. 3288.

The authors greatly appreciate the Maine Agricultural Center for funding this research project and Katherine Garland and Julie Hawkins for providing advice and assistance.

We gratefully acknowledge Longfellow's Greenhouses, Coastal Maine Botanical Gardens, the Bangor Garden Show, and the Portland Flower Show for allowing us to survey attendees at their spring events. We thank Marianne Sarrantonio and Katherine Garland for reviewing an early draft of this manuscript.

${ }^{1}$ Department of Plant, Soil, and Environmental Sciences, University of Maine, 5722 Deering Hall, Orono, ME 04469

${ }^{2}$ University of Maine Cooperative Extension, 495 College Avenue, Orono, ME 04473

${ }^{3}$ Corresponding author. E-mail: sburnett@maine.edu. public (Dillman, 2000; Salant and Dillman, 1994). Our results should be extrapolated accordingly. Surveys generally took less than 5 min to complete. Completed surveys were placed in a secured box to protect subjects' confidentiality.

The first question in the survey was intended to identify active gardeners. Participants who did not identify themselves as active gardeners were directed to not answer plant-related questions, but were forwarded to demographics questions [questions 8-11 (Table 1)] to capture a wider view of our population demographics. Accordingly, survey results for plant-related data included only those respondents who actually made plant-purchasing decisions.

On the survey, respondents were provided with definitions of conventional, organic, sustainable, and local plants to ensure consistent definitions as the foundation for the survey questions. Conventional plants were defined as those that make no claims regarding origin or type of production. Organic plants were defined as those that were produced with limited chemical applications, that have passed a certification process from a regulatory agency [e.g., USDA, ME Organic Farmers and Gardeners Association (Unity, ME), California Organic (Santa Cruz, CA)], or both. Sustainable plants were defined as those produced in a facility that emphasized environmentally friendly practices such as recycling, alternative energy sources, fair labor practices, and low fertilizer runoff. A local plant was defined as a plant produced within 200 miles $(321.9 \mathrm{~km})$ from where it is being sold.

Upon completion of the sampling, surveys were assigned a numeric code for identification and data entry. This numeric code was entered into an Excel ${ }^{\circledR}$ (Microsoft, Redmond, WA) spreadsheet, in which each survey was represented and each response variable had a corresponding numeric code. If a response was left blank, the response was not used in subsequent analysis. Anomalies such as multiple responses, or unclear demarcations were also coded as "no response." The one exception to this was question 7 , which asked about respondents' motives for purchasing an organic plant. A large number of respondents chose both responses: "these plants are healthier for the individual/family," and "these plants are more environmentally friendly." In these cases, both responses were recorded. For responses to question 8 (family income), nonresponses were included in percentages, but not data analysis, to standardize comparisons between our survey and a national survey published by the National Gardening Association (Burlington, VT).

Data were analyzed using $\chi^{2}$ and Spearman's $\rho$ multivariate correlation analyses in JMP (version 7.0.2; SAS Institute, Cary, NC). A total of 446 surveys were collected according to the following distribution: 202 responses from the Portland Flower Show, 230 responses from the Bangor Garden Show, 9 responses from Longfellow's Greenhouses' open house, and 5 responses from Coastal Maine Botanical Gardens. Responses were first tested to ensure homogeneity of the test population across venues. Survey results from Bangor and Portland venues were compared using $\chi^{2}$ analysis across the demographic categories of gardener status (question 1), plant-purchasing status (question 2), motives for purchasing organics (question 7), income (question 8), education (question 9), age (question 10), and gender (question 11). The results from Longfellow's Greenhouses' open house and Coastal Maine Botanical Gardens were excluded from demographic analysis because of small sample size. Respondents from the Bangor and Portland flower shows did not differ demographically for any of the aforementioned variables except for education. Respondents surveyed in Bangor were significantly more educated than those surveyed in Portland $(P=$ $0.0107)$. Given the relative homogeneity of the population between Bangor and Portland, data from both venues were combined. The two minor venues, the open house at Longfellow's Greenhouses' open house and the Coastal Maine Botanical Gardens event, were then combined with the larger data set for further analysis.

\section{Results and discussion}

DEMOgRAPHIC INFORMATION. Participant responses to questions 811 reflected demographic data for our survey, including family income, education level, age, and gender (Table 1 ). The median family income reported among 396 respondents was $\$ 50,000$ 
Table 1. The survey that was distributed to participants at four venues in Maine in 2008: the Portland Flower Show (Portland, ME), the Bangor Garden Show (Bangor, ME), Longfellow's Greenhouses' open house (Manchester, ME), and the Coastal Maine Botanical Gardens garden show (Boothbay Harbor, ME).

\section{Which of the following apply to you? (Control the SINGLE best answer.) \\ $\square$ I do not purchase plants or make landscape-related decisions for my home. (If you control this box, please skip to Question 8.) \\ $\square$ I casually purchase plants or make occasional landscape decisions for my home. \\ $\square$ I frequently purchase plants or make many landscape decisions for my home. \\ $\square$ I professionally purchase plants or landscape and charge for my service.}

\section{Which ONE of the following statements best describes the majority of your plant purchasing?}

$\square$ I purchase plants to use in my home (landscape or container garden).

$\square$ I purchase plants to use in my apartment (landscape or container garden).

$\square$ I purchase plants to use in a community (community garden, church, etc.).

$\square$ I purchase plants as part of my business.

$\square$ Other (please specify):

3. In the year 2007, estimate how much money you spent on the following types of plants.

\begin{tabular}{|l|l|l|l|l|l|l|l|l|l|} 
& $\$ 0$ & $\begin{array}{l}\$ 1- \\
\$ 25\end{array}$ & $\begin{array}{l}\$ 26- \\
\$ 50\end{array}$ & $\begin{array}{l}\$ 51- \\
\$ 75\end{array}$ & $\begin{array}{l}\$ 76- \\
\$ 100\end{array}$ & $\begin{array}{l}\$ 101- \\
\$ 250\end{array}$ & $\begin{array}{l}\$ 251- \\
\$ 500\end{array}$ & $\begin{array}{l}\$ 501- \\
\$ 1000\end{array}$ & Above \$1000 \\
\hline $\begin{array}{l}\text { Edible } \\
\text { Vegetable/Herb } \\
\text { Plants }\end{array}$ & & & & & & & & & \\
\hline $\begin{array}{l}\text { Ornamental Flowers } \\
\text { \& Perennials }\end{array}$ & & & & & & & & & \\
\hline $\begin{array}{l}\text { Other Plants/ Trees, } \\
\text { Shrubs } \\
\text { Groundcovers }\end{array}$ & & & & & & & & & \\
\hline
\end{tabular}

\section{Circle a SINGLE number in each line below to indicate how interested you would be in purchasing the} described plants.

Type of Plant

Conventional ${ }^{\mathrm{z}}$ vegetable or herb plants

Organic $^{y}$ vegetable or herb plants

Sustainable ${ }^{\mathrm{x}}$ vegetable or herb plants

Local $^{\mathrm{w}}$ vegetable or herb plants

Conventional flowers and perennials

Organic flowers and perennials

Sustainable flowers and perennials

Local flowers and perennials

\begin{tabular}{|l|l|l|l|l|l|l|l|l|l|l|}
\hline \multicolumn{9}{|c|}{ Low Interest } & \multicolumn{6}{|c|}{ High Interest } \\
\hline 1 & 2 & 3 & 4 & 5 & 6 & 7 & 8 & 9 & 10 \\
\hline 1 & 2 & 3 & 4 & 5 & 6 & 7 & 8 & 9 & 10 \\
\hline 1 & 2 & 3 & 4 & 5 & 6 & 7 & 8 & 9 & 10 \\
\hline 1 & 2 & 3 & 4 & 5 & 6 & 7 & 8 & 9 & 10 \\
\hline 1 & 2 & 3 & 4 & 5 & 6 & 7 & 8 & 9 & 10 \\
\hline 1 & 2 & 3 & 4 & 5 & 6 & 7 & 8 & 9 & 10 \\
\hline 1 & 2 & 3 & 4 & 5 & 6 & 7 & 8 & 9 & 10 \\
\hline 1 & 2 & 3 & 4 & 5 & 6 & 7 & 8 & 9 & 10 \\
\hline
\end{tabular}

5. The following table deals with VEGETABLE or HERB PLANTS. What is the greatest price increase (if any) that you would be willing to pay for the listed types of plants when compared with the cost of a Conventional Plant? For each plant type listed on the left, control ONE box:

\begin{tabular}{|l|l|l|l|l|l|l|l|l|l|l|}
\hline & $\begin{array}{l}\text { Would } \\
\text { not buy } \\
\text { plant }\end{array}$ & $\begin{array}{l}\text { Expect } \\
\text { to pay } \\
\text { the } \\
\text { same }\end{array}$ & $\begin{array}{l}\text { Up to } \\
10 \% \\
\text { more }\end{array}$ & $\begin{array}{l}\text { Up to } \\
15 \% \\
\text { more }\end{array}$ & $\begin{array}{l}\text { Up to } \\
25 \% \\
\text { more }\end{array}$ & $\begin{array}{l}\text { Up to } \\
35 \% \\
\text { more }\end{array}$ & $\begin{array}{l}\text { Up to } \\
45 \% \\
\text { more }\end{array}$ & $\begin{array}{l}\text { Up to } \\
55 \% \\
\text { more }\end{array}$ & $\begin{array}{l}\text { Up to } \\
75 \% \\
\text { more }\end{array}$ & $\begin{array}{l}\text { Up to } \\
100 \% \text { or } \\
\text { More }\end{array}$ \\
\hline Organic & & & & & & & & & & \\
\hline Sustainable & & & & & & & & & & \\
\hline Local & & & & & & & & & & \\
\hline
\end{tabular}


Table 1. (Continued) The survey that was distributed to participants at four venues in Maine in 2008: the Portland Flower Show (Portland, ME), the Bangor Garden Show (Bangor, ME), Longfellow's Greenhouses' open house (Manchester, ME), and the Coastal Maine Botanical Gardens garden show (Boothbay Harbor, ME).

6. The following table deals with ORNAMENTAL FLOWERS and PERENNIALS. What is the greatest price increase (if any) that you would be willing to pay for the listed types of plants when compared with the cost of a Conventional Plant? For each plant type listed on the left, control ONE box:

\begin{tabular}{|l|l|l|l|l|l|l|l|l|l|l|}
\hline & $\begin{array}{l}\text { Would } \\
\text { not buy } \\
\text { plant }\end{array}$ & $\begin{array}{l}\text { Expect } \\
\text { to pay } \\
\text { the same }\end{array}$ & $\begin{array}{l}\text { Up to } \\
10 \% \\
\text { More }\end{array}$ & $\begin{array}{l}\text { Up to } \\
15 \% \\
\text { more }\end{array}$ & $\begin{array}{l}\text { Up to } \\
25 \% \\
\text { more }\end{array}$ & $\begin{array}{l}\text { Up to } \\
35 \% \\
\text { More }\end{array}$ & $\begin{array}{l}\text { Up to } \\
45 \% \\
\text { More }\end{array}$ & $\begin{array}{l}\text { Up to } \\
55 \% \\
\text { more }\end{array}$ & $\begin{array}{l}\text { Up to } \\
75 \% \\
\text { More }\end{array}$ & $\begin{array}{l}\text { Up to } \\
100 \% \text { or } \\
\text { More }\end{array}$ \\
\hline Organic & & & & & & & & & & \\
\hline Sustainable & & & & & & & & & & \\
\hline Local & & & & & & & & & \\
\hline
\end{tabular}

\section{In your opinion, what is the SINGLE best reason to purchase Organic plants (edible or ornamental)?}

\begin{tabular}{|l|l|}
\hline$\square$ These plants are healthier for the individual/family. & $\square$ I do not purchase these plants. \\
\hline$\square$ These plants are more environmentally friendly. & $\square$ Other \\
\hline
\end{tabular}

\section{What is your current family income?}

\begin{tabular}{|l|l|l|}
\hline$\square$ Under $\$ 20,000$ & $\square \$ 50,000$ to $\$ 74,999$ & $\square \$ 150,000$ to $\$ 199,999$ \\
\hline$\square \$ 20,000$ to $\$ 34,999$ & $\square \$ 75,000$ to $\$ 99,999$ & $\square \$ 200,000$ to $\$ 249,000$ \\
\hline$\square \$ 35,000$ to $\$ 49,999$ & $\square \$ 100,000$ to $\$ 149,999$ & $\square \$ 250,000$ or higher \\
\hline
\end{tabular}

\begin{tabular}{|l|l|l|}
\hline \multicolumn{3}{|l|}{ 9. What is your level of education? (Indicate highest level of education attained.) } \\
\hline$\square$ Less than High School & $\square$ Some Post-High School & $\square$ College Graduate \\
\hline$\square$ High School Equivalency & $\square$ Technical School & $\square$ Post-Graduate \\
\hline
\end{tabular}

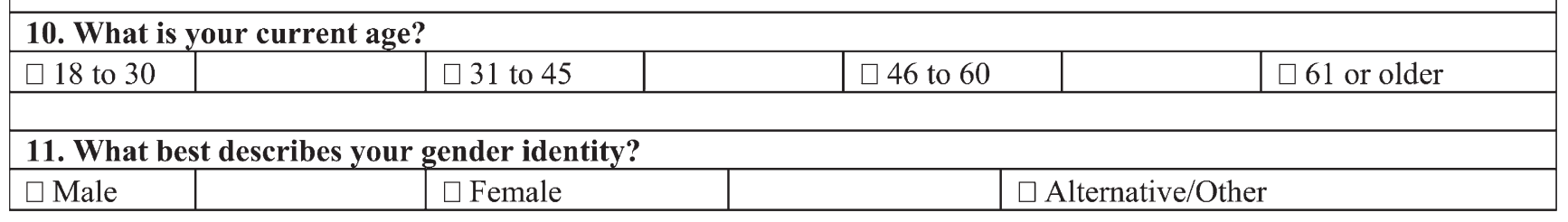

\footnotetext{
${ }^{2}$ Conventional: A plant that makes no claims regarding its origin or type of production.

'Organic: A plant that is produced with limited chemical applications and/or has passed a certification process from a regulatory agency (e.g., USDA, ME Organic Farmers and Gardeners, CA Organic).

${ }^{x}$ Sustainable: A plant produced in a facility that emphasizes environmentally friendly practices such as recycling, alternative energy sources, fair labor practices, and low fertilizer runoff.

"Local: A plant that is grown within 200 miles $(321.9 \mathrm{~km})$ from where it is being sold.
}

to $\$ 74,999$. This compares to a median family income of $\$ 48,763$ for Portland and $\$ 42,047$ for Bangor according to U.S. census data (U.S. Department of Commerce, 2000a). Corrected for inflation to 2008 using an inflation calculator (U.S. Bureau of Labor Statistics, 2010), this would correspond to median family incomes of \$60,969 for Portland and \$53,274 for Bangor. In a National Gardening Association survey of food gardeners, $22 \%$ of respondents had an income of $\$ 75,000$ or over; $16 \%$ had an income of $\$ 50,000$ to 74,$999 ; 24 \%$ were in the $\$ 35,000$ to $\$ 49,999$ bracket; $21 \%$ earned under $\$ 35,000$; and $17 \%$ did not designate an income (Butterfield, 2009). By comparison, $39.7 \%$ of respondents to our survey earned $\$ 75,000$ or more annually; $19 \%$ earned $\$ 50,000$ to $\$ 74,999$; $13.4 \%$ earned $\$ 35,000$ to $\$ 49,999$; $17.7 \%$ under $\$ 35,000$; and $11.2 \%$ did not designate an income no response). Our sample population appeared to have more individuals with higher incomes compared with the National Gardening Association survey of food gardeners, but the median income for respondents was representative for individuals from Portland and Bangor when U.S. census data (U.S. Department of Commerce, 2000a) were corrected for inflation.

None of the surveyed participants reported that they had less than a high school education. Twenty-four individuals $(5.7 \%)$ had a high school equivalency education level, 64 (15.2\%) had some post-high school education, and 21 respondents $(5.0 \%)$ had attended technical school. Most individuals reported that they were collegeeducated; 182 people $(43.1 \%)$ were college graduates, and an additional 131 people $(31.0 \%)$ had postgraduate degrees. These results are comparable to the National Gardening Association survey of food gardeners, where $43 \%$ of participants indicated that they were college graduates, $36 \%$ indicated they had "some college," and $21 \%$ indicated they were high school graduates (Butterfield, 2009).

Age distribution of respondents was as follows: 28 respondents $(6.5 \%)$ were 18-30 years old, 82 respondents (19.0\%) were $31-45$ years old, 228 
respondents $(52.9 \%)$ were $46-60$ years old, and 93 respondents (21.6) were age 61 years or older. For the purposes of comparison, we transformed the census data from the year 2000 to factor out any age brackets below 18 years of age. This allows for all comparisons to be made and percentages to be calculated among populations that are 18 years of age or older. U.S. census data from the year 2000 indicated that $25.5 \%$ of Portland's population and $25.4 \%$ of Bangor's population were between 18 and 29 years of age (U.S. Department of Commerce, 2000b). Thirty-two percent of Portland's citizens were between 30 and 44 years old (Bangor = $28.9 \%) ; 21.4 \%$ were between ages 45 and 59 years (Bangor $=23.3 \%) ; 21.0 \%$ were between ages 45 and 59 years $($ Bangor $=23.3 \%)$; and $21.0 \%$ were 60 years of age or older (Bangor $=22.4 \%)$. Our sample population had fewer young respondents and more participants between the ages of 45 and 60 years (U.S. Department of Commerce, 2000b). But, our data correspond more closely with the National Gardening Association survey of food gardeners in which $24 \%$ of respondents were between ages 45 and 54 years and $44 \%$ of respondents were 55 years old or older (Butterfield, 2009).

Female respondents outnumbered males; 320 participants $(74.6 \%)$ were female and 109 participants (25.4\%) were male. By comparison, the National Gardening Association's survey of food gardeners included 54\% female and $45 \%$ male respondents (Butterfield, 2009). We noted that during our survey process, many male partners deferred the opportunity to take the survey to their female companions. This may partially explain the high number of female survey respondents.

Almost all participants were plant purchasers. Among the respondents to question one, 289 people $(65.9 \%)$ were frequent plant purchasers and an additional 133 people $(30.4 \%)$ were casual plant purchasers (Table 1). 10 people identified themselves as landscape professionals $(2.3 \%)$, while 6 (1.4\%) had no interest in plants. In response to question 2, 384 respondents $(92.8 \%)$ indicated they purchased plants for their home landscape (Table 1$)$. Of the remaining individuals, $16(3.9 \%)$ bought plants for their apartment, $13(3.1 \%)$ bought plants for their

Table 2. Survey participants at the Portland Flower Show (Portland, ME), Bangor Flower Show (Bangor, ME), Longfellow's Greenhouses' open house (Manchester, ME), and the Coastal Maine Botanic Gardens garden show (Boothbay Harbor, ME) $(\mathrm{n}=446)$ were asked to rank their interest in vegetable/ herb or ornamental plants that were grown using conventional, organic, or sustainable techniques, or were locally grown. Interest in all plant types (median) is shown below. The acceptable price increase for each of these plants is also shown.

\begin{tabular}{lllc}
\hline Variable & \multicolumn{1}{c}{ Plant type } & Production type & Median \\
\hline $\begin{array}{c}\text { Consumer interest } \\
(1-10 \text { scale })^{\mathrm{z}}\end{array}$ & Vegetable/Herb & Conventional & 9 \\
& Vegetable/Herb & Organic & 9 \\
& Vegetable/Herb & Sustainable & 9 \\
& Vegetable/Herb & Local & 6 \\
& Ornamental & Conventional & 8 \\
& Ornamental & Organic & 9 \\
& Ornamental & Sustainable & 9 \\
& Ornamental & Local & 6 \\
Acceptable price increase & Vegetable $/$ Herb & Organic & Up to $15 \%$ more \\
& Vegetable $/$ Herb & Sustainable & Up to $15 \%$ more \\
& Vegetable/Herb & Local & Up to $15 \%$ more \\
& Ornamental & Organic & Up to $10 \%$ more \\
& Ornamental & Sustainable & Up to $10 \%$ more \\
& Ornamental & Local & Up to $10 \%$ more \\
\hline
\end{tabular}

${ }^{\mathrm{z}} \mathrm{l}=$ low interest, $10=$ high interest.

y Consumers were asked to identify the percentage price increase they would be willing to pay for organic, sustainable, and local plants compared with the price they typically pay for conventionally grown plants. The acceptable percentage price increase was quantified on a 10-point scale, with responses ranging from "would not buy the plant" to being willing to spend "up to $100 \%$ more" for the plant.

business, and 1 person $(0.2 \%)$ bought plants primarily for a community landscape.

Organic plants. Survey respondents ranked their interest in organic plants on a 10-point scale, where 1 indicated low interest and 10 corresponded to high interest [question 4 (Table 1)]. They then indicated how much more money (if any) they would pay for organic than conventional plants [questions 5-6 (Table 1)]. Their median interest in organic plants was high [9 out of 10 (Table 2)]. Participants stated that they were willing to spend more on both ornamental and vegetable/herb plants when they were grown organically, but would pay slightly more for organic vegetable/herb plants (15\% more) than ornamental plants (10\% more). It is possible that respondents were inherently willing to spend more money on organic vegetable/herb compared with organic ornamental plants. However, demographics of our survey sample indicated that participants' annual spending on ornamental plants was greater compared with vegetable/herb plants (data not shown). Thus, a percentage increase in the cost of ornamental plants could result in a greater overall increase annual spending on ornamental compared with vegetable/herb plants.
For all types of plants (organic, local, and sustainable), it is important to note the survey reported stated, not revealed preferences. Since consumers were asked to indicate the price they would pay for plants in a survey, but were not required to purchase plants, there is the potential for bias in this approach (Cummings, et al., 1995; Fox et al., 1998; List and Shogren, 1998). An alternate approach that has been used to determine consumer willingness to pay for biodegradable containers would be to use auctions in which real money is paid for products (Yue et al., 2010).

Based on responses to question 7 (Table 1), it is also possible that respondents felt a stronger motivation to purchase organic vegetable/herb plants compared with organic ornamental plants. When respondents were asked to identify the single best reason to purchase organic plants, nearly half ( $47.5 \%$ or 200 individuals) felt that "these plants are healthier for the individual/family." An additional $34.1 \%$ of respondents (144 individuals) felt that "these plants are more environmentally friendly." Forty-six people, $10.9 \%$ of respondents selected both of these responses. Of the remaining individuals, 25 people $(5.9 \%)$ would not purchase organic plants and 7 people $(1.7 \%)$ would 
purchase organic plants for another, nonlisted motivation. Since a majority of respondents consider organic plants healthier than conventional, they may have felt that edible plants were worth a slightly higher price premium than ornamental plants. Nonetheless, they indicated that they were willing to pay a higher price for organic than conventionally grown ornamental plants. It is also possible that since the health motive was listed first, some of the response for this motive may be due to primacy effects (Dillman, 2000). However, the extent to which a primacy effect may have affected our results is probably small, given that the list of choices was small.

Previous research indicates that consumers purchase organic products out of the belief that they are healthier (Jolly, 1991), better for the environment (Durham, 2007), better tasting (Zhao et al., 2007), or some combination of the three factors (Nelson et al., 2004) compared with conventional products. Our research indicates that while many factors may be important, the strongest motivator for respondents was concern for health. This could be tied to consumers' safety concerns regarding pesticide contamination. Consumers were very concerned about pesticide contamination of produce, and they considered organic produce to be a remedy for that concern (Bruhn et al., 1992; Williams and Hammitt, 2001). In addition, organic plants may have been perceived to be healthier on a phytochemical/ nutritional level, since some organic foods have higher levels of beneficial vitamins or phytochemicals (Zhao et al., 2006).

Growers may be interested in finding consumers who are the most motivated to purchase nonconventional products. So, to identify those respondents who would be most interested in purchasing organic plants, we correlated respondents' interest level [question 4 (Table 1)] and the amount of money they stated they were willing to spend on organic plants [questions 5-6 (Table 1)] to all demographic variables. All possible correlations were tested, but only those that were significant are presented in Tables 3-5.

Respondents from certain demographic groups were likely to spend more than the average respondent on organic plants. Income and education

Table 3. The amount of money consumers reported spending on vegetable/herb and ornamental plants each year correlated to those consumers' interest in conventional, organic, sustainable, and local vegetable/herb and ornamental plants. Those expenses were also correlated to the acceptable percentage price increase for unconventional plants compared with conventional plants $(n=446)$. Participants were surveyed at the Portland Flower Show (Portland, ME), Bangor Flower Show (Bangor, ME), Longfellow's Greenhouses' open house (Manchester, ME), and the Coastal Maine Botanic Gardens garden show (Boothbay Harbor, ME).

\begin{tabular}{lllcr}
\hline Variable & \multicolumn{1}{c}{ Plant type } & $\begin{array}{c}\text { Production } \\
\text { type }\end{array}$ & $\begin{array}{c}\text { Money spent on } \\
\text { plant purchases } \\
\text { in 2007 }\end{array}$ & Pvalue \\
\hline Consumer interest & Vegetable/Herb & Conventional & 0.2082 & $<0.0001$ \\
$(1-10 \text { scale })^{y}$ & Vegetable/Herb & Organic & 0.1744 & 0.0006 \\
& Vegetable/Herb & Sustainable & 0.1817 & 0.0003 \\
& Vegetable/Herb & Local & 0.0685 & 0.1898 \\
& Ornamental & Conventional & 0.0791 & 0.1163 \\
& Ornamental & Organic & 0.1865 & 0.0002 \\
& Ornamental & Sustainable & 0.2114 & $<0.0001$ \\
Acceptable price & Ornamental & Local & 0.1027 & 0.0444 \\
increase & Vegetable/Herb & Organic & 0.1496 & 0.0036 \\
& Vegetable/Herb & Sustainable & 0.1079 & 0.0399 \\
& Vegetable/Herb & Local & 0.0721 & 0.1656 \\
& Ornamental & Organic & 0.0968 & 0.0578 \\
& Ornamental & Sustainable & 0.1431 & 0.0056 \\
& Ornamental & Local & 0.1133 & 0.0263 \\
\hline
\end{tabular}

${ }^{2}$ Data were analyzed using Spearman's rho multivariate correlation analyses and chi-square in JMP (version 7.0.2; SAS Institute, Cary, NC). Spearman's rho values indicate strength and direction of correlation. Higher values represent strong correlation; positive values indicate positive correlation; negative values indicate negative correlation.

${ }^{\mathrm{y}} \mathrm{l}=$ low interest, $10=$ high interest.

${ }^{x}$ Consumers were asked to identify the percentage price increase they would be willing to pay for organic, sustainable, and local plants compared with the price they typically pay for conventionally grown plants. The acceptable percentage price increase was quantified on a 10-point scale, with responses ranging from "would not buy the plant" to being willing to spend "up to $100 \%$ more" for the plant.

level were strong predictors of how much they stated they would be willing to pay for organic plants. Respondents with higher incomes and education levels would spend more on organic plants than those respondents with lower incomes or education levels (Table 4).

Other demographic variables indicated that individuals from certain groups had greater than average interest in organic plants, but did not indicate they would pay more than other respondents for them. The amount of money respondents spent on plants the previous year [question 3 (Table 1)] was a strong indicator of their interest level. The more money respondents spent, the greater their interest in organic plants (Table 3 ). Interest in organic vegetable/herb plants was also negatively correlated with age, suggesting that younger people have a stronger interest in organic plants than older people (Table 5). Earlier studies reported that younger people purchase organic food more regularly than older people and consider organic production important (Onyango et al., 2007; Simonne et al., 2006; Thompson, 1998). Finally, women had higher interest than men in organic vegetable/ herb and ornamental plants (Table 5). Previous research also suggests that women purchase organic food more regularly then men (Onyango et al., 2007).

Sustainable Plants. Respondents had a high interest in sustainable plants [9 out of 10 (Table 2)], and they were willing to spend $10 \%$ (ornamentals) to $15 \%$ (vegetables) more on sustainable plants. Respondents were equally interested in, and stated that they were willing to pay similar amounts for, sustainable and organic plants. This indicates that there is a strong market for sustainable plants. The "sustainable" market currently spends about $\$ 230$ billion annually (Lifestyles of Health and Sustainability, 2010). However, consumers might feel more confident about sustainable plants if the plants are certified "sustainable" through independent companies such as VeriFlora (Scientific Certification Systems, Emeryville, CA) 
Table 4. The stated price increase consumers would find acceptable for organic, sustainable, and local plants vegetable/herb and ornamental plants was correlated to demographic data and responses to pertinent questions to determine which consumers are willing to accept the greatest price increase. All possible correlations were tested, however, only significant correlations are presented. Participants $(n=446)$ were surveyed at the Portland Flower Show (Portland, ME), Bangor Flower Show (Bangor, ME), Longfellow's Greenhouses' open house (Manchester, ME), and the Coastal Maine Botanic Gardens garden show (Boothbay Harbor, ME).

\begin{tabular}{|c|c|c|c|c|}
\hline Variable & Plant type & $\begin{array}{c}\text { Production } \\
\text { type }\end{array}$ & $\begin{array}{c}\text { Acceptable } \\
\text { price increase }\end{array}$ & $P$ value \\
\hline \multirow{6}{*}{$\begin{array}{l}\text { Consumer interest } \\
(1-10 \text { scale })^{y}\end{array}$} & Vegetable/Herb & Organic & $0.2543^{x}$ & $<0.0001$ \\
\hline & Vegetable/Herb & Sustainable & 0.1288 & 0.0115 \\
\hline & Vegetable/Herb & Local & -0.0163 & 0.7554 \\
\hline & Ornamental & Organic & 0.1926 & 0.0002 \\
\hline & Ornamental & Sustainable & 0.1145 & 0.0265 \\
\hline & Ornamental & Local & -0.0365 & 0.4853 \\
\hline \multirow[t]{6}{*}{ Income $^{\mathrm{w}}$} & Vegetable/Herb & Organic & 0.1632 & 0.0016 \\
\hline & Vegetable/Herb & Sustainable & 0.1813 & 0.0005 \\
\hline & Vegetable/Herb & Local & 0.1336 & 0.0102 \\
\hline & Ornamental & Organic & 0.1444 & 0.0056 \\
\hline & Ornamental & Sustainable & 0.1336 & 0.0114 \\
\hline & Ornamental & Local & 0.1052 & 0.0440 \\
\hline \multirow[t]{6}{*}{ Education $^{v}$} & Vegetable/Herb & Organic & 0.1189 & 0.0177 \\
\hline & Vegetable/Herb & Sustainable & 0.1205 & 0.0185 \\
\hline & Vegetable/Herb & Local & 0.0736 & 0.1466 \\
\hline & Ornamental & Organic & 0.0418 & 0.4105 \\
\hline & Ornamental & Sustainable & 0.0341 & 0.5085 \\
\hline & Ornamental & Local & 0.0080 & 0.8758 \\
\hline
\end{tabular}

${ }^{\mathrm{z}}$ Consumers were asked to identify the percentage price increase they would be willing to pay for organic, sustainable, and local plants compared with the price they typically pay for conventionally grown plants. The acceptable percentage price increase was quantified on a 10 -point scale, with responses ranging from "would not buy the plant" to being willing to spend "up to $100 \%$ more" for the plant.

$y_{1}=$ low interest, $10=$ high interest.

xData were analyzed using Spearman's rho multivariate correlation analyses and chi-square in JMP (version 7.0.2 SAS Institute, Cary, NC). Spearman's rho values indicate strength and direction of correlation. Higher values represent strong correlation; positive values indicate positive correlation; negative values indicate negative correlation.

"Income was quantified on a nine-point scale, with responses ranging from "under $\$ 20,000$ " to " $\$ 250,000$ or higher."

"Education was quantified on a six-point scale, with responses ranging from "less than high school" to "postgraduate."

and MPS [Honselersdijk, Netherlands (Lopez et al., 2008)].

As with organic plants, respondent interest level and the amount of money they stated they were willing to spend on sustainable plants was correlated to demographic variables (Tables 3-5). One important predictor was income; individuals with higher incomes were willing to spend more money on sustainable plants (Table 4). Also, those respondents with higher education levels were likely to spend higher amounts of money on sustainable vegetable/herb plants than participants with less education. However, education level did not significantly impact the amount of money respondents would spend on ornamental plants. Robinson and Smith (2003) also reported that more educated consumers hold supportive beliefs toward sustainable food. However, our research suggests that this may not extend to ornamental plants.

Respondents who spent the most money on plants annually [question 3 (Table 1)] were more interested in sustainable vegetable/herb and ornamental plants than respondents who spend less annually (Table 3 ). Interest in sustainably grown vegetable/herb and ornamental plants was also correlated with income. Our findings support research by Robinson and Smith (2003), who reported that higher income groups were more likely to hold supportive beliefs toward sustainable food (Table 5). Similarly to organic plants, young people expressed greater interest in sustainable vegetable/herb and ornamental plants than older people (Table 5). It should be noted, though, that Robinson and Smith (2003) reported that older people actually hold more supportive beliefs toward buying sustainable food compared with younger people. Our younger survey respondents were highly interested in sustainable plants, but would not pay more for them than other respondents. It is possible that younger respondents have lower incomes, which may prevent them from paying an extra $10 \%$ to $15 \%$ for sustainable plants. Women also had higher interest than men in sustainable vegetable/herb and ornamental plants (Table 5). This is not surprising since women hold supportive beliefs toward sustainable food than men (Robinson and Smith, 2003).

LOCAL PLANTS. Interest in local plants was lower than interest in any other type of plant, including conventional plants. Median interest in local ornamental and vegetable/herb plants was 6 out of 10 or just above average (Table 2). Despite this low interest in local plants, respondents were willing to spend up to $15 \%$ more on local plants compared with conventional plants (Table 2). Although respondents were less interested in local plants, they were willing to pay the same price for them as they were for organic and sustainable plants. Yue and Tong (2009) similarly observed that consumers would pay similar amounts for organic and local food, and Loureiro and Hine (2002) reported that consumers would pay more for "Colorado grown" potatoes (Solanum tuberosum) than conventional ones. Consumers may have had several reasons to be interested in local plants and produce. They could have considered them safer, particularly in the case of vegetable/ herb plants (Govindasamy et al., 2008). Consumers could have considered them of higher quality and less expensive, particularly if sold through a farmers' market (Brown, $2002,2003)$. The market for local plants may overlap with that for sustainable, organic plants, or both. For example, consumers were willing to pay the most for both apples and chestnuts that were both local and organic (Aguilar et al., 2009; Wang et al., 2010).

There were several predictors, which indicated which respondents were likely to pay more for local plants than most respondents. Those individuals who spent more money on plants the previous year were all likely to pay more for local ornamental 
Table 5. Significant correlations between consumers' $(n=446)$ interest in sustainable, local, and organic vegetable/herb and ornamental plants and various demographic factors are shown. Participants were surveyed at the Portland Flower Show (Portland, ME), Bangor Flower Show (Bangor, ME), Longfellow's Greenhouses' open house (Manchester, ME), and the Coastal Maine Botanic Gardens garden show (Boothbay Harbor, ME).

\begin{tabular}{lllcl}
\hline Variable & \multicolumn{1}{c}{ Plant type } & $\begin{array}{c}\text { Production } \\
\text { type }\end{array}$ & $\begin{array}{c}\text { Consumer } \\
\text { interest }(\mathbf{1}-\mathbf{1 0} \text { scale })^{\mathrm{z}}\end{array}$ & $\boldsymbol{P v a l u e}^{\mathbf{P} \text { valu }}$ \\
\hline Income $^{\mathrm{y}}$ & Vegetable/Herb & Sustainable & $0.0931^{\mathrm{x}}$ & 0.0718 \\
& Ornamental & Sustainable & 0.1145 & 0.0266 \\
Education $^{\mathrm{w}}$ & Vegetable/Herb & Organic & 0.1291 & 0.0107 \\
& Vegetable/Herb & Sustainable & 0.0919 & 0.0657 \\
& Vegetable/Herb & Local & 0.1299 & 0.0120 \\
Age $^{\mathrm{v}}$ & Vegetable/Herb & Organic & -0.0907 & 0.0708 \\
& Vegetable/Herb & Sustainable & -0.1231 & 0.0127 \\
& Ornamental & Sustainable & -0.0876 & 0.0768 \\
Gender $^{\mathrm{u}}$ & Vegetable/Herb & Organic & 0.1286 & 0.0104 \\
& Vegetable/Herb & Sustainable & 0.1178 & 0.0174 \\
& Ornamental & Organic & 0.1509 & 0.0026 \\
& Ornamental & Sustainable & 0.1710 & 0.0005 \\
& Ornamental & Local & 0.1030 & 0.0442 \\
\hline
\end{tabular}

${ }^{\mathrm{z}} \mathrm{l}=$ low interest, $10=$ high interest.

yncome was quantified on a nine-point scale, with responses ranging from "under $\$ 20,000$ " to " $\$ 250,000$ or higher."

'Data were analyzed using Spearman's rho multivariate correlation analyses and chi-square in JMP (version 7.0.2; SAS Institute, Cary, NC). Spearman's rho values indicate strength and direction of correlation. Higher values represent strong correlation; positive values indicate positive correlation; negative values indicate negative correlation.

"Education was quantified on a six-point scale, with responses ranging from "less than high school" to "postgraduate."

"Age was quantified on a four-point scale, with responses ranging from "18 to 30 years" to "61 years or older." "Gender was quantified on a three-point scale with responses for "male," "female," and "alternative." The latter response did not include sufficient response volume and was coded as a non-response. Positive correlations indicate females were more likely to have higher interest than males.

plants (Table 3). Also, as with organic and sustainable plants, respondents with higher incomes stated they were likely to spend more money on local plants (Table 4).

Several demographic variables were correlated with interest in local plants. Women were more interested than men in local plants (Table 5). And, more educated respondents were more interested in local vegetable/ herb plants than respondents with less education (Table 5). Henseleit et al. (2007) reported that there were no clear demographic trends among those who purchase local foods. This contrasts with our survey in which we observed that income, gender, and education level were important predictors for which respondents were most interested in or willing to pay more for local plants.

Our data suggest that there is a market for organic, sustainable, and local plants, and that growers could charge a price premium for these plants compared with conventional plants. Respondents' high interest in organic and sustainable plants, and their willingness to pay up to $15 \%$ more for organic, sustainable and local plants, suggests that they perceive a higher value in these plants compared with conventionally grown plants. Growing organic or sustainable plants, or possibly even marketing plants as locally grown, could be a valuable niche market.

Organic growers are motivated because they consider growing organic "the right thing to do" rather than because of perceived price premiums for organic products (Burnett and Stack, 2009; Walz, 2004). By comparison, only $7 \%$ of organic growers considered the market for organic ornamental plants to be a strong motivator. In 2009, Hall et al. reported that most greenhouse growers $(65 \%$ of respondents to a national survey) consider adopting sustainable practices an important step to protecting to environment, but fewer growers are interested in certifying their plants as sustainable. In order for growers to have access to organic, sustainable, and local plant markets, it is vital to communicate to them that their customers are interested in these plants and willing to pay more for them than for conventional plants. Further, outreach and research could help growers overcome barriers to adopting new production techniques. For example, conventional bedding plant growers considered fertility and substrate management and insect and disease management significant challenges in organic production that would serve as barriers to transitioning to this production technique (Burnett and Stack, 2009). Assisting growers to overcome these barriers could encourage more growers to adopt alternative production strategies.

\section{Conclusions}

Survey respondents' had a high level of interest in organic and sustainable vegetable/herb and ornamental plants. Their interest in organic and sustainable plants and edible and ornamental plants was comparable. Gardeners indicated that they were willing to pay up to a median of $15 \%$ more for organically, sustainably, and locally grown plants than for conventional plants. However, these gardeners were willing to accept a greater price increase for organic, sustainable or local vegetable/herb plants compared with their ornamental counterparts. Several factors predicted which respondents were willing to spend the most money on sustainable and organic plants. Respondents who spent the most money on plants in previous years were more willing to spend a higher amount on sustainable and organic vegetable/ herb and ornamental plants. Those individuals with higher incomes and higher education levels were also more likely to spend more on organic and sustainable plants. Younger respondents and women expressed higher interest in nonconventional plants; however, their interest did not correspond to an increase in the amount of money they would be willing to pay for plants. Respondents' interest in organic and sustainable plants and their willingness to pay up to $15 \%$ more for these plants compared with conventional plants supports the claim that there is a market for organic and sustainable vegetable/herb and ornamental plants. If plants can be produced with reasonable profit margins, organic and sustainable container production could be profitable niche markets.

\section{Literature cited}

Aguilar, F.X., M.M. Cernusca, and M.A. Gold. 2009. Exploratory assessment of 
consumer preferences for chestnut attributes in Missouri. HortTechnology 19:216-223.

Blanke, M.M. and B. Burdick. 2005. Food (miles) for thought - Energy balance and locally-grown versus imported apple fruit. Environ. Sci. Pollution Res. 12:125-127.

Brown, A. 2002. Farmers' market research 1940-2000: An inventory and review. Amer. J. Altern. Agr. 17:167-176.

Brown, C. 2003. Consumers' preferences for locally produced food: A study in southeast Missouri. Amer. J. Altern. Agr. $18: 213-224$

Bruhn, C.M., K. Diazknauf, N. Feldman, J. Harwood, G. Ho, E. Ivans, L. Kubin, C. Lamp, M. Marshall, S. Osaki, G. Stanford, Y. Steinbring, I. Valdez, E. Williamson, and E. Wunderlich. 1992. Consumer food safety concerns and interest in pesticide-related information. J. Food Saf. 12:253-262.

Burnett, S.E. and L.B. Stack. 2009. Survey of the research needs of the potential organic ornamental bedding plant industry in Maine. HortTechnology 19:743-747.

Butterfield, B. 2009. The impact of home and community gardening in America. National Gardening Assn., South Burlington, VT.

Cummings, R.G., G.W. Harrison, and E.E. Rutström. 1995. Homegrown values and hypothetical surveys: Is the dichotomous choice approach incentive-compatible? Amer. Econ. Rev. 85:260-266.

Darby, K., M.T. Batte, S. Ernst, and B. Roe. 2008. Decomposing local: A conjoint analysis of locally produced foods. Amer. J. Agr. Econ. 90:476-486.

Dillman, D.A. 2000. Mail and internet surveys: The tailored design method. 2 nd ed. Wiley, New York, NY.

Durham, C.A. 2007. The impact of environmental and health motivations on the organic share of produce purchases. Agr. Resource Econ. Rev. 36:304-320.

Fox, J.A., J.F. Shogren, D.J. Hayes, and J.B. Kliebenstein. 1998. CVM-X: Calibrating contingent values with experimental auction markets. Amer. J. Agr. Econ. 80:455-465.

Govindasamy, R., C.G. Turvey, and V. Purduri. 2008. The influence of agroterrorism on consumers' preference for locally grown products: A case-study from New Jersey. Appl. Econ. Lett. 15:991-995.

Hall, T.J., J.H. Dennis, R.G. Lopez, and M.I. Marshall. 2009. Factors affecting growers' willingness to adopt sustainable floriculture practices. HortScience 44: 1346-1351.

Henseleit, V.M., S. Kubitzki, D. Schotz, and R. Teuber. 2007. Consumer preferences for locally produced foods - A representative analysis of the influencing factors. Berichte Uber Landwirtschaft 85:214-237.

Jolly, D.A. 1991. Determinants of organic horticultural products consumption based on a sample of California consumers. Acta Hort. 295:141-148.

Krug, B.A., S.E. Burnett, J.H. Dennis, and R.G. Lopez. 2008. Growers look at operating a sustainable greenhouse. GMPro $28: 43-45$.

Lifestyles of Health and Sustainability. 2010. Lifestyles of Health and Sustainability Online. 30 Aug. 2010. <http://www. lohas.com>.

List, J.A. and J.F. Shogren. 1998. Calibration of the difference between actual and hypothetical valuations in a field experiment. J. Econ. Behav. Organ. 37:193-205.

Lopez, R.G., S.E. Burnett, B.A. Krug, and J.H. Dennis. 2008. 8 steps to take to become sustainable. GMPro 29:26-29.

Loureiro, M.L. and S. Hine. 2002. Discovering niche markets: A comparison of consumer willingness to pay for local ( $\mathrm{Col}-$ orado grown), organic, and GMO-free products. J. Agr. Appl. Econ. 33:477-487.

Nelson, L., J. Giles, C. Macilwain, and V. Gewin. 2004. Organic FAQs. Nature 428:796-798.

Onyango, B.M., W.K. Hallman, and A.C. Bellows. 2007. Purchasing organic food in US food systems-A study of attitudes and practice. Br. Food J. 109:399-411.

Pollan, M. 2006. The omnivore's dilemma: A natural history of four meals. Penguin Press, London, UK.

Robinson, R. and C. Smith. 2003. Associations between self-reported health conscious consumerism, body-mass index, and attitudes about sustainably produced foods. Agr. Human Values 20:177-187.

Robinson, R., C. Smith, H. Murray, and J. Ennis. 2002. Promotion of sustainably produced foods: Customer response in Minnesota grocery stores. Amer. J. Altern. Agr. 17:96-104.

Salant, P. and D.A. Dillman. 1994. How to conduct your own survey. Wiley, New York, NY.

Simonne, A.H., B.K. Behe, and M.M. Marshall. 2006. Consumers prefer lowpriced and high lycopene-content fresh-market tomatoes. HortTechnology 16:674-681.

Sloan, A.E. 2005. Top 10 global food trends. Food Technol. 59:20-24.

Thompson, G.D. 1998. Consumer demand for organic foods: What we know and what we need to know. Amer. J. Agr. Econ. 80:1113-1118.

U.S. Bureau of Labor Statistics. 2010. Inflation calculator. 20 July 2010. <http:// data.bls.gov/cgi-bin/cpicalc.pl>.

U.S. Department of Agriculture. 2006. Data sets: Organic production. 26 Mar. 2007. <http://www.ers.usda.gov/Data/ Organic $/>$.

U.S. Department of Commerce. 2000a. Census data. Family income. 24 Feb. 2010. <http://www.state.me.us/spo/economics/docs/townleveldata/fam_inc.pdfs.

U.S. Department of Commerce. 2000b. Census data. Age sex. 24 Feb. 2010. <http://www.state.me.us/spo/economics/ docs/townleveldata/agesex.pdf $>$.

Walz, E. 2004. Final results of the fourth national organic farmer's survey: Sustaining organic farms in a changing organic marketplace. Organic Farming Res. Foundation, Santa Cruz, CA.

Wang, Q., J. Sun, and R. Parsons. 2010. Consumer preferences and willingness to pay for locally grown organic apples: Evidence from a conjoint study. HortScience 45:376-381.

Willer, H. and M. Yussefi. 2004. The world of organic agriculture: Statistics and emerging trends. Intl. Federation Organic Agr. Movements, Bonn, Germany.

Williams, P.R.D. and J.K. Hammitt. 2001. Perceived risks of conventional and organic produce: Pesticides, pathogens, and natural toxins. Risk Anal. 21:319-330.

Yue, C.Y. and C. Tong. 2009. Organic or local? Investigating consumer preference for fresh produce using a choice experiment with real economic incentives. HortScience 44:366-371.

Zhao, X., E.E. Carey, W.Q. Wang, and C.B. Rajashekar. 2006. Does organic production enhance phytochemical content of fruit and vegetables? Current knowledge and prospects for research. HortTechnology 16:449-456.

Zhao, X., E. Chambers, Z. Matta, T.M. Loughin, and E.E. Carey. 2007. Consumer sensory analysis of organically and conventionally grown vegetables. J. Food Sci. 72:S87-S91. 